\title{
The quality of ice cream samples made from buffalo milk
}

\author{
Hatice Bekiroğlu' ${ }^{1}$, Salih Özdemir ${ }^{2}$ (D)
}

Cite this article as:

Bekiroğlu, H., Özdemir, S. (2020). The quality of ice cream samples made from buffalo milk. Food and Health, 6(1), 20-26.

https://doi.org/10.3153/FH20003

${ }^{1}$ Yıldız Technical University, Chemical and Metallurgical Engineering Faculty, Food Engineering Department, 34210 Istanbul, Turkey

${ }^{2}$ Atatürk University, Agriculture Faculty, Food Engineering Department, 25240 Erzurum, Turkey

\section{ORCID IDs of the authors:}

H.B. 0000-0003-3328-1550

S.Ö. 0000-0002-9583-4379

Submitted: 30.05 .2019

Revision requested: 17.07.2019

Last revision received: 26.08 .2019

Accepted: 04.09.2019

Published online: 05.12.2019

Correspondence:

Hatice BEKİROĞLU

E-mail: h.bkroglu@gmail.com

\begin{abstract}
The aim of this study was to evaluate physical, chemical and organoleptic properties the ice creams made from buffalo milk, cow milk, and their mix during storage for 21 days. Before the cow milk ice-cream samples were made, cow milk was standardized to fat ratio of $7.10 \%$ with fresh cow milk cream. The highest acidity values were determined in ice cream samples made from buffalo milk using the alkali titration method. The $\mathrm{pH}$ of ice cream samples was found at between 6.44 and 6.60. The average $\mathrm{pH}$ of ice cream samples was found as 6.53 . The overrun values of ice cream samples ranged from $34.10 \%$ to $43.23 \%$ and the highest overrun values were determined in samples made with buffalo and cow milk mix. The first melting time of ice cream samples was between $1109 \mathrm{~s}$ and 1510s. Generally, the first melting time of ice cream samples made from buffalo milk was longer than that of only cow milk ice cream samples. The highest $\mathrm{L}$ color value was determined at ice cream samples made from only buffalo milk. Generally, buffalo milk ice cream samples were preferred by the panelist with the highest scores when compared with ice cream samples made from cow and mix of cow and buffalo milk. As a result, it can be surely said that the use of buffalo milk in dairy products such as ice cream enriches the sensory, chemical and physical properties of the product.
\end{abstract}

Keywords: Ice cream, Buffalo milk, Melting time, Overrun, Acidity, L color value

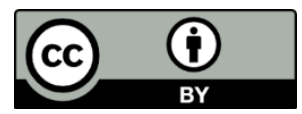

CCopyright 2020 by ScientificWebJournals Available online at

http://jfhs.scientificwebjournals.com 


\section{Introduction}

Ice cream is a very desirable dairy product that has been consumed by everyone from seven to seventy in worldwide. Ice cream is a dessert making from milk, sugar, additives including stabilizer, may also contain other food products such as fruits, which enhances its nutritive value same as sales. Recent studies show that ice cream plays a fundamental role in our diets, which consume great amounts of it. Generally, cow milk is used to ice cream production in many countries of the world. Buffalo milk contains butter fat at a high level. For this reason, generally, buffalo milk is used at dry cream making. However, buffalo milk contains higher calcium and protein. But, the cholesterol level of buffalo milk is lower than that of cow milk (Zicarelli 2004). Although buffalo milk contains more lactose than the cow milk, lactose intolerance problem sourcing from buffalo milk is less (Ahmad et al., 2013).

Buffalo milk has a higher value than the other milk types in terms of the amount of mineral matter as well as the fat content (Cashman 2002a, b). In particular, the amount of B12, riboflavin and folic acid is higher than other milk kinds whereas folate binding capacity is lowest of buffalo milk (Sharma et al., 2007). Oligosaccharides, which form a large part of lactose in the milk and contribute to the realization of many vital and biological functions, are found in high quantities in buffalo milk compared to other milk varieties (Martinez-Ferezet al., 2006). Since the buffalo milk has a high dry matter content, it can be used in many milk products, but also contributes to energy saving in production poses (Ahmad, et al., 2013).

When cow milk was used at ice cream making, milk must be fortified with fresh cream. Because buffalo milk contains fat at high level, the ice-cream can be produced from buffalo milk unless fat adding. Milk fat increases the body, texture, homogeneity and organoleptic properties of ice cream samples. The fat ratio must be minimum of $8 \%$ for hard ice cream and for 7\% for soft ice cream (Hamilton 1990). However, the color of buffalo milk is whiter than that of cow milk. This state will be effected as positive to color of ice cream. There is paper at limiting number according to the buffalo milk ice cream. Minhas et al. (2002) made ice cream from buffalo milk with different stabilizators and found that when the viscosity of ice cream increased, the organoleptic properties increased too. Guven et al. (2002) made Turkish Maras ice cream from goat milk and found that the average overrun ratio and $\mathrm{pH}$ degree of samples were $21.74 \%$ and 6.58 respectively. Akalın and Gonc (1995) made the cow milk ice cream and found that viscosity and overrun ratio of samples were between $5622 \mathrm{mPa} . \mathrm{s}-7324 \mathrm{mPa} . \mathrm{s}$ and $28.02 \%-40.10 \%$, respectively. Simsek et al. (2006) made ice cream from cow milk with different stabilizers and found that $\mathrm{pH}$ and first melting time were between 6.31-6.39 and 36.63- $75.63 \mathrm{~min}$, respectively. Ozdemir et al. (2003) made ice cream for diabetic patients and found that the $\mathrm{pH}$, viscosity and overrun were among 6.50- 6.77, $2350 \mathrm{mPa} . \mathrm{s}-6020 \mathrm{mPa} . \mathrm{s}$ and 26.30\%-37.52\%, respectively. Konar and Akin (1992) made ice cream samples from cow, sheep and goat milk and found that sheep milk ice cream had the highest viscosity than that of other samples. The objective of this study was to compare the buffalo milk ice cream quality and cow milk ice cream quality.

\section{Materials and Methods}

\section{Materials}

Buffalo milk samples used in ice cream making were taken from milk producers in Erzurum. Cow milk samples and raw cream were taken from Ataturk University Pilot Milk Plant. Sugar, salep, emulgator and plastic containers and glass were purchased in Erzurum.

\section{Methods}

\section{The preparation of ice cream samples}

In this research, buffalo milk, cow milk standardized with fresh cream and buffalo and cow milk mix (1:1) were used for ice cream making. Because the fat ratio of the buffalo milk was $7.1 \%$, the fat ratio of cow milk was standardized to $7.1 \%$ too. Milk samples of $3 \mathrm{~kg}$ (buffalo, cow and buffalo and cow mix) were heated to $40^{\circ} \mathrm{C}$ and added to milk the $550 \mathrm{~g}$ sugar, $30 \mathrm{~g}$ stabilizer (salep) and $10 \mathrm{~g}$ emulgator. Mix was pasteurized at $78^{\circ} \mathrm{C}$ for 10 minutes. Then, the mix was cooled to $5^{\circ} \mathrm{C}$ and ripened at same temperature for 24 hours. The ice cream samples were prepared in ice cream machinery and hardened in deep freezer $\left(-18^{\circ} \mathrm{C}\right)$. Samples were taken at $1,7,15$ and 21 days of storage periods and analyzed. Ice cream samples were produced in triplicate.

\section{The analysis of milk, cream and mix samples}

The dry matter, fat, acidity and $\mathrm{pH}$ analysis of milk, cream and mix samples was made as Kurt et al. (2007). The dry matter was performed using an air circulation oven (Memmert UF110, Germany). The fat content of samples was measured by Gerber Method using Gerber centrifuge machine (Funke Gerber 12105, Germany). The $\mathrm{pH}$ value was measured using a digital pH meter (model WTW pH-340-A, Weilheim, Germany). The acidity was determined by the alkali titration method using sodium hydroxide $(0.1 \mathrm{~N})$ and the results were expressed in ${ }^{\circ} \mathrm{SH}$ (Soxhlet Henkel).

\section{The analysis of ice cream samples}

The viscosity of ice cream mix samples was calculated by 
Viscositmetry (Polten RY-8). The calculation of viscosity was made at $20 \mathrm{rpm}$ using 0,5 no spindle (Abrahamsen and Holman, 1980). The $\mathrm{pH}$ value was measured using a digital $\mathrm{pH}$ meter. Before analysis, $\mathrm{pH}$ meter was standardized (Kurt et al., 2007). Overrun was calculated according to the equation [(volume of ice cream $)-($ volume of mix $) /$ volume of mix $\times 100]$ given by Jimenez et al., (1993). First melting time that expressing the strength and structural properties of ice cream was determined according to the method UM 0801 described by Anonymous (1997). Color analysis of samples was made with Minolta Data Processor DP- 300 series. Results were given as L, a, b degrees (Chroma Meter, CR-200, Osaka, Japan; Anonymous, 1979). The sensory evaluation of the ice cream samples was performed by 7 panelists selected from the academic staff of food engineering department via the use of a score test for flavor, body and texture, color and appearance, resistance to melting, creamy taste, unacceptable taste and general acceptability. Hardened ice cream samples were tested at a serving temperature of $-10^{\circ} \mathrm{C}$. The sensory characteristics were assessed on a scale from 1 , for very poor, to 9, for excellent (Roland et al., 1999). Ice cream samples were served to participants selected from nonsmokers who had previous sensory analysis experience at serving temperature $\left(-10^{\circ} \mathrm{C}\right)$. Warm water and bread were provided to the panelists among two samples in order to find out the differences between the samples easier to perceive.

The data were analyzed using of variance (SPSS 13.0 for Windows) and Duncan's new multiple range tests were done using the SAS program (Y1ldiz and Bircan, 1991).

\section{Results and Discussion}

The total solid, fat and $\mathrm{pH}$ results of buffalo milk, cow milk and fresh cream were given Table 1.

The physical and chemical analysis results of ice cream samples were given in Table 2 .

Table 1. The some physical and chemical properties buffalo milk, cow milk, raw cream and mixes used at making of ice cream samples

\begin{tabular}{lllllll}
\hline Analyses & $\begin{array}{l}\text { Buffalo } \\
\text { Milk }\end{array}$ & $\begin{array}{l}\text { Cow } \\
\text { Milk }\end{array}$ & Raw Cream & $\begin{array}{l}\text { Buffalo Ice } \\
\text { Cream Mix }\end{array}$ & $\begin{array}{l}\text { Cow Ice } \\
\text { Cream Mix }\end{array}$ & $\begin{array}{l}\text { Buffalo and } \\
\text { Cow Mix }\end{array}$ \\
\hline $\begin{array}{l}\text { Drymatter } \\
\text { (\%) }\end{array}$ & 17.25 & 12.73 & 54.50 & 33.12 & 31.96 & 32.32 \\
Fat (\%) & 7.10 & 3.4 & 51.00 & 7.10 & 7.20 & 7.15 \\
pH & 6.68 & 6.43 & 6.55 & 6.59 & 6.43 & 6.40 \\
\hline
\end{tabular}

Values represent means of triplicates

Table 2. Physical and chemical analysis results of ice cream samples.

\begin{tabular}{llllllllcc}
\hline $\begin{array}{l}\text { Ice Cream } \\
\text { Samples }\end{array}$ & $\begin{array}{l}\text { Storage } \\
\text { Time (Days) }\end{array}$ & $\begin{array}{l}\text { Acidity } \\
\text { (SH) }\end{array}$ & $\mathbf{p H}$ & $\begin{array}{l}\text { First Dripping } \\
\text { Time (Second) }\end{array}$ & $\begin{array}{l}\text { Overrun } \\
(\%)\end{array}$ & $\begin{array}{l}\text { Viscosity } \\
(\mathbf{c P})\end{array}$ & $\begin{array}{c}\text { Color } \\
\text { L }\end{array}$ & $\begin{array}{c}\text { Color } \\
\text { a }\end{array}$ & $\begin{array}{c}\text { Color } \\
\text { b }\end{array}$ \\
\hline (A) & 1 & 10.67 & 6.55 & 1510 & 41.0 & 4420 & 108.5 & -1.15 & 3.54 \\
Buffalo Milk & 7 & 9.03 & 6.54 & 1386 & 43.2 & 4550 & 105.6 & -1.17 & 3.44 \\
Ice Cream & 14 & 8.88 & 6.55 & 1455 & 42.0 & 3955 & 102.3 & -1.18 & 3.21 \\
& 21 & 8.43 & 6.64 & 1465 & 42.0 & 3975 & 106.5 & -1.15 & 3.36 \\
\hline (B) & 1 & 7.90 & 6.52 & 1109 & 42.3 & 1440 & 81.4 & -3.35 & 8.29 \\
Cow Milk Ice & 7 & 6.51 & 6.47 & 1165 & 42.0 & 1685 & 79.6 & -3.83 & 7.73 \\
Cream & 14 & 6.71 & 6.53 & 1183 & 42.0 & 2805 & 80.0 & -3.16 & 7.49 \\
& 21 & 7.21 & 6.59 & 1124 & 41.0 & 2010 & 81.5 & -3.38 & 8.07 \\
\hline (C) & 1 & 8.90 & 6.44 & 1202 & 34.1 & 5735 & 102.4 & -1.92 & 6.43 \\
Buffalo and & 7 & 8.92 & 6.57 & 1276 & 37.0 & 4350 & 100.2 & -1.78 & 6.67 \\
Cow Milk Ice & 14 & 8.96 & 6.60 & 1215 & 35.2 & 6150 & 101.6 & -2.10 & 5.89 \\
Cream & 21 & 8.45 & 6.49 & 1275 & 36.0 & 4650 & 101.5 & -1.83 & 6.32 \\
\hline
\end{tabular}

Values represent means of triplicates 
From the analyses results of ice cream samples, the average $\mathrm{pH}$ value of buffalo ice cream samples was found as 6.53 . The results were paralleled with results of Ozdemir et al. (2003). But, the $\mathrm{pH}$ degrees $(6.31-6.39)$ found by Simsek et al. (2006) were lower than that of our results. It was observed that there were no significant changes when the $\mathrm{pH}$ and acidity $(\mathrm{SH})$ values of the ice cream samples are examined during storage. The differences in the first dripping times and color values of the ice cream samples were determined to be insignificant. The first dripping times of ice creams made from buffalo milk were prolonged compared to cow milk ice cream. We want that the ice cream can be stay in mouth longer time. The buffalo milk ice cream can be maintained structure for a longer time that is a feature requested in the ice cream industry.

It is well known that the overrun of ice cream is related to its structure and general quality. Overrun is related to not only effect consistency of ice cream but also effect nutritive value, firmness, to be eat status and productive of ice cream (Arbuckle 1986). According to results (Table 2), overrun values ranged from $34.10 \%$ to $43.23 \%$ and highest overrun values were determined in samples made from only buffalo milk or cow milk. When buffalo and cow milk mixed, the overrun ratio decreased. This state can be sourced different protein structures of cow and buffalo milk. The overrun ratios found at ice creams added stevia by Ozdemir et al. (2015) were lower that of the research founds. Flores and Goff (1999) found that a slight decrease in mean ice crystal size caused increase of overrun. These effects may be related to the change in heat transfer rates from the ice cream upon increased aeration. Wilbey et al. (1997) found a decrease in hardness of ice cream caused to increased overrun. However, Prindiville et al. (1999) and Abd El-Rahman et al. (1997) found the opposite effect other factors (air cell and ice crystal size distributions) had more effect on hardness than total overrun. This finding was likely as the overrun value of recent research.

The viscosity of ice cream that has a major influence on sensory and texture quality is determined in particular. The viscosity of ice cream is one of the most important parameter to be shown that ice cream structure. The viscosity values in samples were varied from $1440 \mathrm{mPa}$.s to $6150 \mathrm{mPa}$.s and it's the highest values were detected in ice cream of mix buffalo and cow milk mix when compared each to other. Using milk that has high dry matter or mix of sort of milk could be of particular importance in the case of developing new products. Except for the ice cream samples made from cow milk, the viscosity values decreased during storage times.

The color parameters $(L, a, b)$ of varieties of ice creams were given in Table 2 . The $\mathrm{L}$ values indicate whiteness of the ice cream samples and its values ranged from 79.06 to 108.5 . The highest $\mathrm{L}$ values determined in ice cream samples made from buffalo milk depending on nature of buffalo milk. Consumers generally prefer whiter ice cream.

The differences of color values of the ice cream samples were determined to be insignificant.

Organoleptic attributes such as color, body and texture, melting resistance of ice creams is showed in this sensory analysis that was made by the panelist (Table 3). When the results of sensory analysis were examined, it was seen that the highest color scores belong to buffalo milk ice cream. In a similar study carried out by Guimarães and Silva (2014), buffalo milk ice cream was found more preferable than cow milk ice cream and cow- buffalo mix ice cream in terms of sensory properties such as color and flavor, although not statistically different.

Use of buffalo milk helped in enhancing the color, body and texture and flavor quality. Especially sensory characteristics are the most important parameter that can be caused increase consumer acceptability. Generally, buffalo ice cream samples were preferred by the panelist with highest scores for total evaluation in most of sensory characteristics when compared with ice cream made from cow and mix of cow-buffalo milk.

\section{Conclusion}

In this study, we determined that based on physical, chemical properties of ice cream with made from buffalo, cow and mix of this milk and compared theirs as the total quality. At results of the research we found that quality of buffalo milk ice cream was remarkable higher than that of ice cream of cow milk. Based on results, adequate evidence has been provided to support the lots of benefits to structure and texture of using milk has high dry matter as buffalo milk. 
Table 3. Sensory analysis results of ice cream samples

\begin{tabular}{|c|c|c|c|c|c|c|c|c|c|c|c|}
\hline 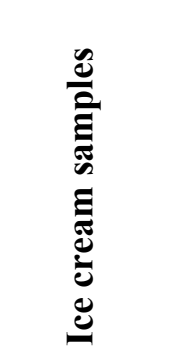 & 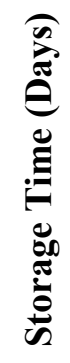 & $\frac{\dot{\theta}}{\dot{\theta}}$ & 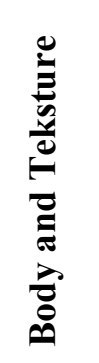 & 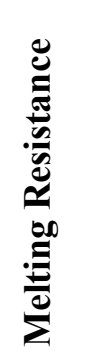 & 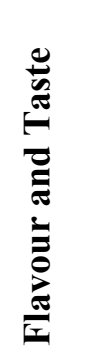 & 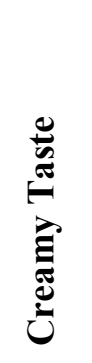 & 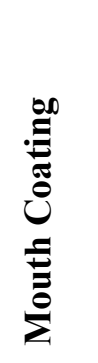 & 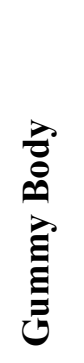 & $\begin{array}{l}\frac{\lambda}{0} \\
0 \\
0 \\
0\end{array}$ & 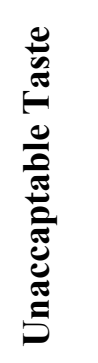 & 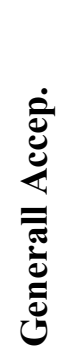 \\
\hline \multirow{4}{*}{$\begin{array}{l}\text { (A) } \\
\text { Buffalo } \\
\text { Milk Ice } \\
\text { Cream }\end{array}$} & 1 & 9.00 & 8.50 & 9.00 & 9.00 & 9.00 & 9.00 & 9.00 & 8.25 & 9.00 & 9.00 \\
\hline & 7 & 8.00 & 8.75 & 8.50 & 8.25 & 8.75 & 8.50 & 8.50 & 8.00 & 8.75 & 9.00 \\
\hline & 14 & 8.75 & 9.00 & 8.50 & 8.00 & 9.00 & 8.50 & 8.50 & 9.00 & 8.50 & 8.50 \\
\hline & 21 & 8.75 & 8.75 & 9.00 & 8.00 & 8.75 & 8.00 & 8.75 & 8.75 & 8.25 & 8.50 \\
\hline \multirow{4}{*}{$\begin{array}{l}\text { (B) } \\
\text { Cow Milk } \\
\text { Ice Cream }\end{array}$} & 1 & 7.57 & 7.00 & 7.00 & 7.25 & 7.00 & 7.25 & 6.25 & 5.25 & 7.00 & 7.00 \\
\hline & 7 & 7.25 & 6.25 & 6.00 & 6.25 & 5.25 & 5.25 & 5.00 & 5.00 & 8.00 & 6.25 \\
\hline & 14 & 6.25 & 6.25 & 6.00 & 6.25 & 5.25 & 5.00 & 4.00 & 5.00 & 7.50 & 6.50 \\
\hline & 21 & 6.00 & 6.25 & 6.00 & 6.00 & 5.00 & 4.50 & 4.25 & 5.25 & 7.50 & 5.25 \\
\hline$(\mathrm{C})$ & 1 & 9.00 & 8.25 & 8.25 & 8.25 & 8.50 & 8.00 & 8.75 & 8.25 & 8.00 & 8.50 \\
\hline \multirow{3}{*}{$\begin{array}{l}\text { Buffalo } \\
\text { and Cow } \\
\text { Milk Ice } \\
\text { Cream }\end{array}$} & 7 & 8.00 & 8.00 & 8.00 & 8.50 & 8.75 & 8.00 & 9.00 & 8.00 & 7.75 & 9.00 \\
\hline & 14 & 8.75 & 8.00 & 8.50 & 8.50 & 8.50 & 8.50 & 9.00 & 7.75 & 7.75 & 8.50 \\
\hline & 21 & 8.00 & 8.00 & 8.50 & 8.50 & 8.50 & 8.50 & 8.50 & 8.00 & 8.00 & 8.00 \\
\hline
\end{tabular}

Values represent means of triplicates

\section{Compliance with Ethical Standard}

Conflict of interests: The authors declare that for this article they have no actual, potential or perceived the conflict of interests.

Ethics committee approval: No ethics committee approval is needed.

\section{References}

Abd El-Rahman, S.A., Madkor, F., Ibrahim, F.S., Kilara, A. (1997). Physical characteristics of frozen desserts made with cream, anhydrous milk fat, or milk fat fractions. Journal of Dairy Science, 80, 1926-1935.

https://doi.org/10.3168/jds.S0022-0302(97)76133-2

Abrahamsen, R.K., Holman, T.B. (1980). Yoghurt from hyperfiltrated, unfiltrated and evaporated milk and from milk with added milk powder. Milchwissenshaft, 35(7), 398-402.
Ahmad, S., Anjum, F.M., Huma N., Sameenand, A., Zahoor T. (2013). Composition and physico-chemical characteristics of buffalo milk with particular emphasis on lipids, proteins, minerals, enzymes and vitamins. The Journal of Animal and Plant Sciences, 23(1 Suppl.), 62-74.

Akalın, A.S., Gonc, S. (1995). Dondurma teknolojisinde kullanılan katkı maddelerinin özellikleri, işlevleri ve yasal durumları (II), asitler, tuzlar, tatlılaştırıcı maddeler, emulsifiye ve stabilize ediciler. Ege Üniversitesi Ziraat Fakültesi Dergisi, 2(32), 201-207.

Anonymous (1979). Farbmetrische bestimmung von farbabstanden bci körperfarben nach der CIELAB formol, p. 30, Beuth-Vertrieb GMbH, Berlin.

Anonymous (1997). Determination of shape retention and meltdown, UMA 0801, Netherland. 
Arbuckle, W.S. (1986). Ice Cream, pp. 68- 69, Chapman and Hall, New York.

https://doi.org/10.1007/978-1-4757-5447-6

Cashman, K.D. (2002a). Trace elements in milk and dairy products, Nutritional Significance. In: Roginski, H., Fox PF, Fuquay JW. (Eds.), Encyclopedia of Dairy Sciences. London, UK: Academic Pres: 2058-2065.

https://doi.org/10.1016/B0-12-227235-8/00732-X

Cashman, K.D. (2002b). Macrominerals in milk and dairy products, Nutritional Significance. In: Roginski, H., Fox PF, Fuquay, J. W. (Eds.), Encyclopedia of Dairy Sciences. London, UK: Academic Pres: 2051-2058.

https://doi.org/10.1016/B0-12-227235-8/00628-3

Flores, A.A., Goff, H.D. (1999). Recrystallization in ice cream after constant and cycling temperature storage conditions as affected by stabilizers. Journal of Dairy Science, 82, 1408-1415.

https://doi.org/10.3168/jds.S0022-0302(99)75367-1

Guimarães, D.H.P., Silva, F.R.d.S.R. (2014). Dairy products production with buffalo milk. International Journal of Applied Science and Technology, 4(3), 14-19.

Guven, M., Karaca, O.B., Kacar, A. (2002). Keçiboynuzu sakız ve diğer stabilizerlerle kombine kullanmanın Kahramanmaraş tipi dondurmaların fizikokimyasal ve duyusal nitelikleri üzerine etkileri. TUBITAK Proje No: TARP2532, Adana.

Hamilton, M.P. (1990). Ice Cream Manufacture. Symposium paper. International Journal of Dairy Technology, 43(1), 17-20.

https://doi.org/10.1111/j.1471-0307.1990.tb02758.x

Jimenez F.R., Klipfel, N.J., Tobias, J. (1993). Ice cream and frozen desserts. Y.H Hui (Ed.), Dairy Science and Technology Handbook, Volume 2: Product Manufacturing, VCH Publishers Inc, New York, pp. 57-157.

Konar, A., Akın, M.S. (1992). İnek ve koyun sütlerinden üretilen dondurmaların kimyasal, fiziksel ve duyusal bazı özelliklerinin saptanması üzerine karşılaştırmalı bir araştırma. Doğa, 16, 711-720.
Kurt, A., Cakmakcı, S., Caglar, A. (2007). Süt ve mamulleri muayene ve analiz metotları rehberi. Atatürk Üniversitesi Yayınları, No: 252/D, 254 s, Erzurum.

Martinez-Ferez, A., Rudloff, S., Guadix, A., Henkelm, C. A., Pohlentz, G., Boza J.J. (2006). Goat's milk as a natural source of lactose derived oligosaccharides: Isolation by Membrane Technology. International Dairy Journal, 16(2), 173-181.

https://doi.org/10.1016/j.idairyj.2005.02.003

Minhas, K.S., Sidhu J.S., Mudahar, G.S., Singh, A.K. (2002). Flow behavior characteristics of ice cream mix made with buffalo milk and various stabilizers. Plant Foods for $\mathrm{Hu}$ man Nutrition, 57(1), 25-40.

Ozdemir, C., Arslaner, A., Ozdemir, S., Allahyari, M. (2015). The production of ice cream using stevia as a sweetener. Journal of Food Science and Technology, 52(11), 75457548 .

https://doi.org/10.1007/s13197-015-1784-5

Ozdemir, C., Dagdemir, E., Celik, S., Ozdemir, S. (2003). An alternative ice cream production for diabetic patients. Milchwissenschaft, 58(3/4), 164-166.

Prindiville, E.A., Marshall, R.T., Heyman, H. (1999). Effect of milk fat on the sensory properties of chocolate ice cream. Journal of Dairy Science, 82, 1425-1432. https://doi.org/10.3168/jds.S0022-0302(99)75369-5

Roland, A.M., Philips, L.G., Boor, K.J. (1999). Effects of fat content on the sensory properties, melting, color, and hardness of ice cream. Journal of Dairy Science, 82, 32-38. https://doi.org/10.3168/jds.S0022-0302(99)75205-7

Sharma, R., Rajputt, Y. S., Dogra, G., Tomar, S. K. (2007). Estimation of vitamin B12 by ELISA and its status in milk. Milchwissenschaft, 62, 127-131.

Simsek, O., Tuncay, I., Bilgin, B. (2006). 3:(1), Endüstriyel dondurma üretiminde farklı stabilizator kullanımının dondurma kalitesine etkisi. Tekirdag Ziraat Fakultesi Dergisi, 3(1), 55-60. 
Wilbey, R.A., Cooke, T., Dimos, G. (1997). The effects of solute concentration, overrun and storage on the hardness of ice cream. W. Buchheim (Ed.), Ice Cream, International Dairy Federation, Germany, 186-187.

Yıldız, N., Bircan, H. (1991). Uygulamalı İstatistik (Genisletilmis 2.Bask1). Atatürk Üniviversitesi Ziraat Fakültesi
Yayın No:35, Erzurum.

Zicarelli, L. (2004). Buffalo Milk: Its properties, dairy yield and mozzarella production. Veterinary Research Communications, 28, 127-135.

https://doi.org/10.1023/B:VERC.0000045390.81982.4d 